\title{
Bitter Leaves Ethanol Extract (Vernonia amygdalina) Decreases Total Cholesterol Serum Level of Hypercholesterolemic Male Wistar Rats
}

\author{
Ivana C Hasan*, Hendra Subroto**, Grace Puspasari*** \\ *Faculty of Medicine Maranatha Christian University \\ **Department of Clinical Pathology Faculty of Medicine Maranatha Christian University \\ ***Department of Biochemistry Faculty of Medicine Maranatha Christian University \\ Jl. Prof. Drg. Surya Sumantri no 65 Bandung 40164 Indonesia \\ Email :ivanacalst@gmail.com
}

\begin{abstract}
Dyslipidemia is the risk factors of atherosclerosis that can cause coronary heart disease. Nowadays, bitter leaf (Vernoniaamygdalina) is known as a plant to decrease plasma lipid. The aim of this study is to know the effects of bitter leaf ethanol extract towards decreasing the total cholesterol serum levels on male Wistar rats which is induced by High Fat Feeding (HFF). The method is a true experimental laboratory with a completely randomized design. Antidyslipidemia effect is tested with HFF induction and Propiltiourasil $0.01 \%$ towards 30 rats which are divided into 6 groups: groups I as normal control (standard diet), groups II, III, and IV are given ethanol extract of bitter leaf dose $100 \mathrm{mg} / \mathrm{kgBW}, 200 \mathrm{mg} / \mathrm{kgBW}$, and 400 $m g / k g B W$, group $V$ as positive control (Simvastatin), and group VI as negative control (aquades). HFF is given for 14 days then the treatment for the next 14 days. The percentage data of the declining total cholesterol levels before and after treatments is analyzed with ANAVA, and continued with LSD test. The result between group II, III, and IV with group VI shows a significant difference $p<0.01$. The conclusion is that bitter leaf ethanol extract can lower the level of total cholesterol serum.
\end{abstract}

Keywords: bitter leaf, Vernonia amygdalina, total cholesterol, hypercholesterolemia, Simvastatin 


\title{
Ekstrak Etanol Daun Afrika (Vernonia amygdalina) Menurunkan Kadar Kolesterol Total Serum pada Tikus Wistar Jantan dengan Hiperkolesterolemia
}

\author{
Ivana C Hasan*, Hendra Subroto**, Grace Puspasari**** \\ * Fakultas Kedokteran Universitas Kristen Maranatha \\ **Bagian Patologi Klinik Fakultas Kedokteran Universitas Kristen Maranatha \\ ****Bagian Biokimia Fakultas Kedokteran Universitas Kristen Maranatha \\ Jl. Prof.Drg.Surya Sumantri, MPH No 65 Bandung 40164 Indonesia \\ Email : ivanacalst@gmail.com
}

\begin{abstract}
Abstrak
Hiperkolesterolemia,merupakan salah satu faktor risiko penting pada aterosklerosis. Daun Afrika menjadi salah satu tanaman yang telah banyak dikenal mampu menurunkan kadar lemak dalam darah. Tujuan penelitian ini menilai efek ekstrak etanol daun Afrika terhadap penurunan kadar kolesterol total serum tikus Wistar jantan dengan hiperkolesterolemia. Ini merupakan Metode penelitian ini eksperimental laboratorik sungguhan dengan Rancangan Acak Lengkap. Efek anti kolesterol diuji pada 30 ekor tikus Wistar jantan yang diinduksi pakan tinggi lemak dan Propiltiourasil 0,01\% kemudian dibagi menjadi 6 kelompok. Kelompok I kontrol normal (pakan standar), kelompok II, III, dan IV diberi ekstrak etanol daun Afrika dosis 100 $\mathrm{mg} / \mathrm{kgBB}, 200 \mathrm{mg} / \mathrm{kgBB}$, dan $400 \mathrm{mg} / \mathrm{kgBB}$, kelompok V kontrol positif (Simvastatin), dan kelompok VI kontrol negatif (akuades). Pakan tinggi lemak diberikan selama 14 hari dilanjutkan dengan perlakuan selama 14 hari. Data persentase penurunan kadar kolesterol total sebelum dan setelah perlakuan dianalisis dengan ANAVA, dilanjutkan dengan Uji LSD. Hasil penelitian antara kelompok II, III, dan IV dengan kelompok VI menunjukkan perbedaan yang bermakna $p<0,01$. Kesimpulannya ekstrak etanol daun Afrika menurunkan kadar kolesterol total serum pada tikus dengan hiperkolesterolemia.
\end{abstract}

Kata Kunci: daun Afrika, Vernonia amygdalina, kolesterol total, dyslipidemia, Simvastatin 


\section{Pendahuluan}

Perubahan gaya hidup masyarakat zaman sekarang dapat memberikan dampak buruk bagi kesehatan seperti pola mengonsumsi makanan yang tinggi lemak, jarang berolah raga, kebiasaan merokok, dan kurang aktifitas fisik. Gaya hidup tersebut dapat menyebabkan menumpuknya lemak di dalam tubuh dan dapat menyebabkan berbagai macam penyakit seperti hipertensi, hiperkolesterolemia, serta dapat memicu terjadinya penyakit jantung koroner. ${ }^{1}$

Aterosklerosis adalah penyakit dimana terjadi penimbunan plak di dalam arteri, sehingga pasokan oksigen berkurang, dan hiperkolesterolemia merupakan faktor risiko penting terjadinya ateroklerosis. ${ }^{3}$

Penyakit kardiovaskuler, utamanya penyakit jantung koroner (PJK) menyebabkan banyak kematian di dunia. Terdapat beberapa faktor risiko yang berperan seperti kebiasaan merokok, hipertensi, dislipidemia dan diabetes-melitus. ${ }^{4}$ Di Indonesia, prevalensi penyakit jantung koroner tahun 2013 sebesar 0,5\% (883.447 orang), sedangkan yang bergejala sebesar $1,5 \% .^{5}$

Saat ini sudah banyak tersedia obat untuk mengatasi hiperkolesterolemia, akan tetapi obat-obat tersebut memiliki banyak efek samping. Oleh karena itu diupayakan produk penurun kolesterol yang berasal dari herbal. ${ }^{6}$

Salah satu tanaman yang secara empiris sudah digunakan sebagai penurun kolesterol adalah daun Afrika. Daun Afrika dipercaya dapat mengobati berbagai penyakit lain seperti diabetes, penyakit jantung, kolesterol. Daun Afrika (Vernonia amygdalina) berasal daerah tropis Afrika yang awalnya digunakan sebagai bumbu masakan. Tanaman ini dapat tumbuh dengan mudah dan cepat, memiliki masa hidup yang lama dan banyak terdapat di Indonesia sehingga mudah diperoleh. ${ }^{7}$

Penelitian oleh Kalvari (2015) dilakukan untuk menguji efek rebusan daun Afrika terhadap penurunan kadar kolesterol total dibandingkan dengan Simvastatin. Rebusan daun Afrika dengan dosis 0,2 gram/ tikus/ hari diberikan sampai H78. Hasil penelitian ini menunjukkan bahwa daun Afrika berefek menurunkan kadar kolesterol total serum tikus Wistar jantan dengan signifikan. ${ }^{8}$ Penelitian lain juga dilakukan oleh Oluwatosin dkk., 2008 untuk menguji efek ekstrak metanol daun Afrika dalam menurunkan kadar lipid darah. Hasil penelitian ini menunjukkan bahwa ekstrak metanol daun Afrika dosis $100 \mathrm{mg} / \mathrm{kgBB}$ dan 200 $\mathrm{mg} / \mathrm{kgBB}$ berefek menurunkan kadar lipid dalam darah dengan signifikan. ${ }^{7}$

Tujuan dari penelitian ini adalah menguji efek ekstrak etanol daun Afrika terhadap kadar kolesterol total serum. 


\section{Metode}

Desain penelitian ini adalah eksperimental laboratorik sungguhan, dengan Rancangan Acak Lengkap (RAL) terhadap tikus Wistar jantan yang diinduksi eksogen dengan pakan tinggi lemak (PTL). Sebelum pengambilan darah, tikus dipuasakan selama 16 jam. Pengambilan darah dilakukan dari ujung ekor tikus, masing-masing sebanyak 1,5 $\mathrm{ml}$ untuk dilakukan pemeriksaan kadar kolesterol total. Darah kemudian disentrifugasi dengan kecepatan 3000 rpm selama 10 menit, dan serum dipisahkan lalu dimasukkan ke dalam tabung Eppendorf. Pemeriksaan kadar kolesterol total akan dilakukan dengan alat Chemistry Analyzer SF-1904C, dengan enzim cholesterol oxidase-phenol aminophenazone (CHOD-PAP) = enzymatic photometric test

Penelitian dilakukan di Laboratorium Farmakologi Klinik Fakultas Kedokteran Umum Universitas Padjajaran/ Rumah Sakit Hasan Sadikin, Bandung dan Fakultas Kedokteran Universitas Kristen Maranatha, Bandung dengan waktu penelitian Desember 2017 sampai Juli 2018. Pada penelitian ini digunakan sampel sebanyak 5 ekor tikus dengan 6 kelompok perlakuan; total sampel yang digunakan adalah 30 ekor. Tikus diperoleh dari peternakan tikus Institut Teknologi Bandung, berumur 2-3 bulan, dengan berat 180-220 gram. Data yang dianalisis adalah persentase penurunan kadar kolesterol total serum dalam mg/dl antara H14 dan H28. Analisis data ini dilakukan dengan metode ANAVA. Apabila terdapat perbedaan yang bermakna dilanjutkan dengan Post Hoc test LSD, $\alpha=0,05$. Kemaknaan ditentukan berdasarkan nilai $\mathrm{p} \leq 0,05$. Penelitian ini telah mendapat persetujuan dari Komisi Etik Kedokteran Fakultas Kedokteran Univeritas Kristen Maranatha dengan nomor 072/KEP/III/2018.

Pprosedur penelitian ini pertama tikus diadaptasi selama 7 hari dengan diberi pakan standar dan akuades, lalu dilakukan pemeriksaan berat badan (BB1). Setelah proses adaptasi, pada semua tikus dilakukan pemeriksaan kadar kolesterol total serum untuk mendapatkan data awal kadar kolesterol. Selanjutnya tikus dibagi menjadi enam kelompok yaitu kelompok EEDA dosis $100 \mathrm{mg} / \mathrm{kgBB}$, kelompok EEDA dosis $200 \mathrm{mg} / \mathrm{kgBB}$, kelompok EEDA dosis 400 $\mathrm{mg} / \mathrm{kgBB}$, kelompok kontrol positif, kelompok kontrol negatif, dan kelompok kontrol normal. Semua kelompok kecuali kelompok normal diinduksi pakan tinggi lemak (PTL) + PTU 0,01\% selama 14 hari untuk membuat keadaan hiperkolestrolemia. Setelah 14 hari dilakukan penimbangan berat badan tikus (BB2) dan pemeriksaan kadar kolesterol total serum tikus.

Setelah 14 hari sejak pemberian PTL, tiap kelompok tikus diberi perlakuan: Kelompok 1 : pakan standar + akuades, kelompok $2:$ PTL + PTU 0,01\% + EEDA dosis $100 \mathrm{mg} / \mathrm{kgBB}$, kelompok 3: PTL + PTU 0,01\% + EEDA dosis $200 \mathrm{mg} / \mathrm{kgBB}$, kelompok 4: PTL + PTU 0,01\% + EEDA dosis $400 \mathrm{mg} / \mathrm{kgBB}$, kelompok 5: PTL + PTU 0,01\% + Simvastatin, dan kelompok 6: PTL + PTU 0,01\% + akuades. Perlakuan dilakukan selama 14 hari. Pengukuran berat badan 
(BB3) kembali dilakukan pada H21. Pada akhir perlakuan (H28), berat badan tikus ditimbang kembali (BB4) dan lakukan pengambilan darah untuk pengukuran kadar kolesterol total serum setelah perlakuan. ${ }^{7,8}$

\section{Hasil}

Pengujian efek ekstrak etanol daun Afrika (Vernonia amygdalina) terhadap kadar kolesterol total serum pada tikus Wistar jantan yang diinduksi pakan tinggi lemak telah dilakukan terhadap 30 ekor tikus Wistar jantan dan didapatkan hasil rerata dan persentase penurunan kolesterol total pada setiap kelompok yang disajikan pada tabel 1 .

Tabel 1 Persentase Penurunan Kolesterol Total Setiap Kelompok

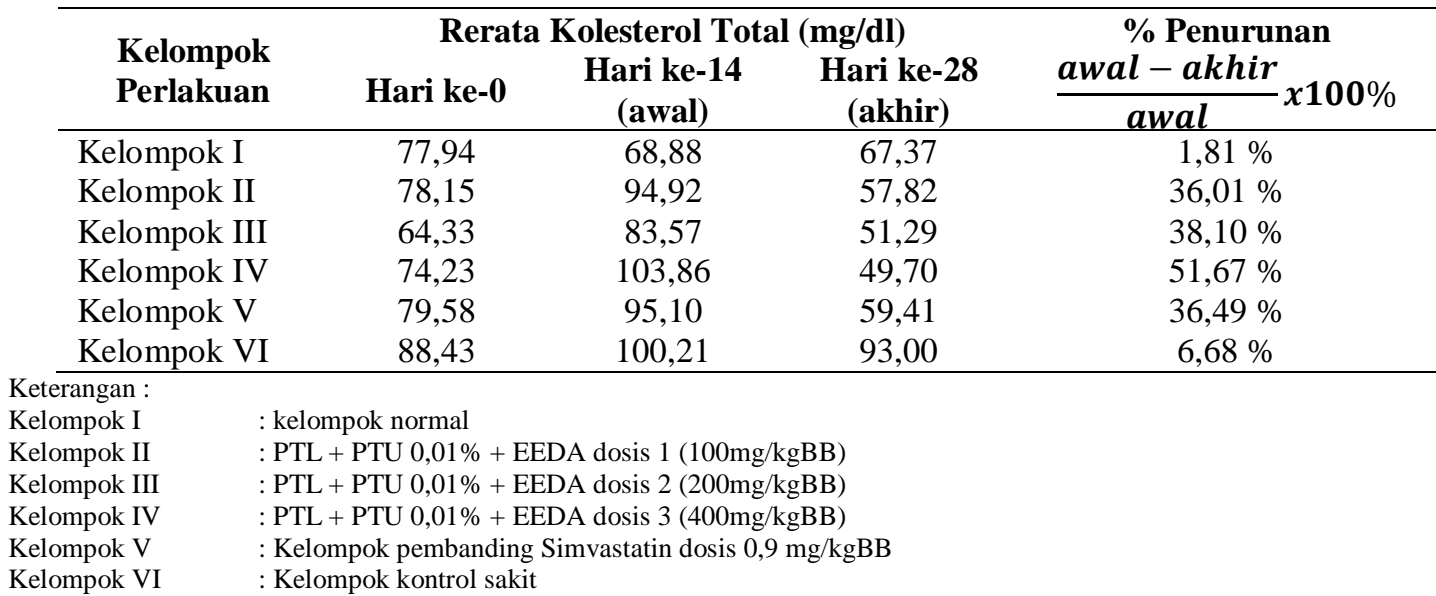

Tabel 1 menunjukkan rerata kolesterol total tiap kelompok pada hari 0, 14, dan 28. Pada kelompok I yang hanya diberikan pakan standar tidak menunjukkan kenaikan rerata pada hari ke 14, sedangkan kelompok II, III, IV, V, dan VI yang diberikan pakan tinggi lemak menunjukkan peningkatan rerata kolesterol total pada hari ke-14. Pada kolom hari ke-28 diperlihatkan rerata kolesterol total setelah diberikan perlakuan. Kelompok yang diberikan ekstrak etanol daun Afrika (kelompok II,III, dan IV) dan Simvastatin menunjukkan adanya penurunan. Hal ini sesuai dengan persentase penurunan kadar kolesterol total dimana kelompok IV (400 mg/KgBB) menunjukkan persentase penurunan yang paling besar yaitu 51,67\%, diikuti oleh kelompok III (200 mg/KgBB) sebesar 38,10\%, kelompok V (Simvastatin) sebesar 36,49\%, dan kelompok II (100mg/KgBB) sebesar 36,01\%. Pada kelompok I dan kelompok VI hanya didapatkan penurunan yang minimal yaitu $1,81 \%$ dan $6,68 \%$.

Hasil rata-rata persentase penurunan kadar kolesterol total serum diuji normalitas Shapiro-Wilk dan didapatkan hasil $p$ value $>0.05$ yang artinya kelompok sudah homogen. 
Dengan demikian data tersebut memenuhi syarat untuk diuji ANAVA satu arah. Hasil uji ANAVA persentase penurunan kolesterol total setelah perlakuan diperoleh nilai $p=0,000$. Hal ini menunjukkan bahwa hasil pengujian kadar kolesterol total tikus berbeda signifikan pada minimal sepasang kelompok perlakuan. Uji statistik dilanjutkan dengan menggunakan uji LSD yang menunjukkan hasil antara kelompok II, III, dan IV berbeda sangat bermakna (masingmasing $p=0,004 ; p=0,002 ; p=0,000$ ) dengan kelompok VI sebagai kontrol negatif yang diberi PTL. Hal ini menunjukkan semua dosis ekstrak etanol daun Afrika berpengaruh secara sangat bermakna dalam menurunkan kadar kolesterol total serum. Hal ini menunjukkan bahwa daun Afrika berefek menurunkan kadar kolesterol total, dapat dilihat pada Gambar 1.

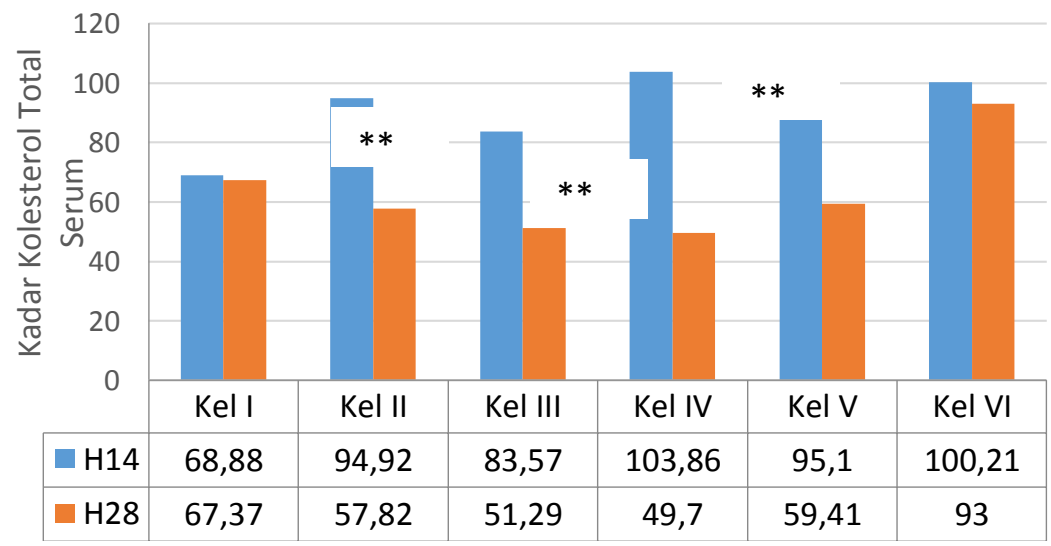

\section{Gambar 1 Diagram Batang Persentase Penurunan Kolesterol Total Setiap Kelompok}

Keterangan :

Kelompok I : Kelompok normal

Kelompok II : PTL + PTU 0,01\% + EEDA dosis $1(100 \mathrm{mg} / \mathrm{kgBB})$

Kelompok III : PTL + PTU 0,01\% + EEDA dosis $2(200 \mathrm{mg} / \mathrm{kgBB})$

Kelompok IV : PTL + PTU 0,01\% + EEDA dosis $3(400 \mathrm{mg} / \mathrm{kgBB})$

Kelompok V : Kelompok pembanding Simvastatin dosis $0,9 \mathrm{mg} / \mathrm{kgBB}$

Kelompok VI : Kelompok kontrol sakit

** : sangat signifikan $(\mathrm{p}<0,01)$ terhadap kelompok V

Potensi efek penurunan kadar kolesterol total dengan ekstrak daun Afrika, dengan cara membandingkan kelompok II, III, dan IV terhadap kelompok V yaitu kelompok yang diberi Simvastatin, menunjukkan perbedaan yang tidak bermakna $(p=0,954 ; p=0,864 ; p=0,116$; $p>0,05)$ sehingga disimpulkan bahwa potensi penurunan kadar kolesterol total dari ekstrak daun Afrika dengan Simvastatin adalah setara. 


\section{Diskusi}

Hasil kelompok perlakuan menunjukkan persentase penurunan terbesar dengan urutan kelompok IV (400 mg/kgBB) sebesar 51,67\%, kelompok III (200 mg/kgBB) sebesar 38,10\%, dan kelompok II (100 mg/kgBB) sebesar 36,01\%. Hasil analisis statistik memperlihatkan bahwa tidak terdapat perbedaan antara kelompok II, III, dan IV. Disimpulkan dosis 1 (100 mg/KgBB) adalah yang paling baik dipilih dibandingkan dengan dosis $2(200 \mathrm{mg} / \mathrm{kgBB})$ dan dosis $3(400$ $\mathrm{mg} / \mathrm{kgBB}$ ) berdasarkan alasan dosis yang terkecil dapat ditimbulkan hasil yang setara dengan dosis yang lebih besar.

Hasil penelitian ini sejalan dengan penelitian oleh Kalvari (2015) dilakukan untuk menguji efek rebusan daun Afrika terhadap penurunan kadar kolesterol total dibandingkan dengan Simvastatin. ${ }^{8}$ Hasil penelitian ini juga sesuai dengan hasil penelitian Oluwatosin dkk., 2008 untuk menguji efek ekstrak metanol daun Afrika dalam menurunkan kadar lipid darah. Pada penelitian ini, induksi kadar lipid dilakukan dengan pemberian kolesterol oral dengan dosis $30 \mathrm{mg} /$ 0,3 $\mathrm{ml}$ dan obat pembanding yang digunakan yaitu Questran dosis terapi 0,26 gram/kgBB. Kolesterol, ekstrak metanol daun Afrika, dan Questran diberikan sebanyak lima kali dalam seminggu selama sembilan minggu. Hasil penelitian ini menunjukkan bahwa ekstrak metanol daun Afrika dosis $100 \mathrm{mg} / \mathrm{kgBB}$ dan $200 \mathrm{mg} / \mathrm{kgBB}$ berefek menurunkan kadar lipid dalam darah dengan signifikan. ${ }^{7}$ Efek tersebut dapat disebabkan oleh berbagai zat yang terkandung dalam daun Afrika yaitu flavonoid, saponin, dan vitamin C.

Flavonoid merupakan antioksidan karena dapat menagkap radikal bebas dengan membebaskan atom hidrogen dari gugus hidroksilnya ${ }^{1}$. Flavonoid mengurangi sintesis kolesterol dengan cara menghambat aktivitas enzim acyl-Coa cholesterol acyl transferase (ACAT) pada sel HepG2 yang berperan dalam penurunan esterifikasi kolesterol pada usus dan hati, serta menghambat aktivitas enzim 3-hidroksi-3-metil-glutaril Coa yang menyebabkan penghambatan sintesis kolesterol. ${ }^{9}$

Saponin dapat menurunkan kadar kolesterol total dengan mengikat garam empedu membentuk suatu senyawa yang tidak dapat diabsorbsi atau membuat garam empedu berikatan dengan polisakarida dalam serat makanan lalu dikeluarkan bersama dengan feses sehingga garam empedu tidak dapat berikatan dengan kolesterol dan kolesterol tidak dapat direabsorbsi. ${ }^{10}$

Vitamin C sebagai antioksidan dapat mencegah proses oksidasi dengan menangkap radikal bebas peroksida, sehingga meminimalisasi terbentuknya LDL teroksidasi. Hal ini menyebabkan LDL lebih mudah dikenali oleh reseptor LDL di hati sehingga mempercepat katabolisme LDL dan clearance kolesterol LDL. ${ }^{11}$ Vitamin ini dapat langsung bereaksi dengan superoksida, anion hidroksil, dan berbagai hidroperoksida lipid. Selain itu, juga dapat berperan 
sebagai anti oksidan sekunder dengan mempertahankan gluthation tereduksi sebagai glutation endogen yang dapat menangkal radikal bebas. ${ }^{12}$

Daun Afrika mengandung alkaloid, saponin, tanin, dan glikosida steroid yang menyebabkan rasa pahit. Daun Afrika juga kaya akan antioksidan (flavonoid, vitamin C) dan senyawa sesquiterpen (vernodalin dan vernomygdin). ${ }^{13}$ Pada penelitian ini didapatkan bahwa ekstrak daun Afrika dapat menurunkan kadar kolesterol total karena berbagai kombinasi zat yang terkandung di dalamnya, yaitu antioksidan polifenol (flavonoid dan saponin) dan vitamin C.

\section{Simpulan}

Ekstrak etanol daun Afrika (Vernonia amygdalina) menurunkan kadar kolesterol total serum.

\section{Daftar Pustaka}

1. Widyaningsih W. Efek Ekstrak Etanol Rimpang Temugiring (Curcuma heyneana Val.) terhadap Kadar Trigliserida. J Vet. 2011;1(1):55-65.

2. Goldberg A. Dyslipidemia [Internet]. 2015 [Cited 2017 Dec 7]. Available from: https://www.msdmanuals.com/professional/endocrine-and-metabolic-disorders/lipid-disorders/dyslipidemia

3. Gibbons G. Atherosclerosis [Internet]. National Heart, Lung, and Blood Institute. 2013 [Cited 2017 Dec 8]. Available from: https://www.nhlbi.nih.gov/health-topics/atherosclerosis

4. Cardiovaskular Diseases (CVDs) [Internet]. WHO. 2013 [Cited 2017 Dec 8]. Available from: http://www.who.int/en/news-room/fact-sheets/detail/cardiovascular-diseases-(cvds)

5. Penyakit Jantung Penyebab Kematian Tertinggi, Kemenkes Ingatkan Cerdik [Internet]. Kemenkes RI. 2017 [cited 2017 Dec 8]. Available from: http://www.depkes.go.id/article/view/17073100005/penyakit-jantung-penyebabkematian-tertinggi-kemenkes-ingatkan-cerdik-.html

6. Erwinanto, Santoso A, Putranto JNE, Tedjasukmana P, Suryawan R, Rifqi S, et al. Pedoman tatalaksana dislipidemia. J Kardiol Indones [Internet]. 2013;34(4):245-70. Available from: http://jki.or.id

7. Oluwatosin A, Akintayo O, Achem J, Michael AF. Lipid-Lowering Effects of Methanolic Extract of Vernonia Amygdalina leaves in Rats Fed High Cholesterol Diet. Vasc Heal Risk Manag. 2008;4:1.

8. Kalvari E. Efek Pemberian Rebusan Daun Afrika (Vernonia amygdalina) terhadap Kadar Kolesterol Total pada Tikus Jantan Galur Wistar yang Diinduksi Pakan Tinggi Lemak. Repository Univ Kristen Maranatha. 2015.

9. Arief M, Novriansyah R, Budianto IT, Bimo M, Harmaji. Potensi Bunga Karamuning (Melastoma malabathricum L.) terhadap Kadar Kolesterol Total dan Trigliserida pada Tikus Putih Jantan Hiperlipidemia yang diinduksi Propiltiourasil. J Prestasi. 2012;1(2):118-26.

10. Cannas A. Departement of Animal Science-Plants Poisonous to Livestock [Internet]. Cornel University. 2015 [Cited 2018 Apr 14]. Available from: http://poisonousplants.ansci.cornell.edu/toxicagents/tannin.html

11. McRae MP. Vitamin C supplementation lowers serum low-density lipoprotein cholesterol and triglycerides: a meta-analysis of 13 randomized controlled trials. J Chiropr Med. 2008;7(2):48-58.

12. Sunarsih E sri, Pamuji S. Pengaruh Pemberian Vitamin C terhadap Kadar Kolesterol total Serum Tikus Jantan Hiperlipidemia Setelah Perlakuan Jus Lidah Buaya (Aloe vera Linn). J Pharm. 2007;5(2):120.

13. Atangwho IJ, Ebong PE, Enyong EU, Williams IO, Eteng MU, Egbung GE. Comparative Chemical Composition of Leaves of Some Antidiabetic Medicinal Plants: Azadirachta Indica, Vernonia Amygdalina and Gongronema Latifolium. African J Biotech. 2009; 8(18): 4685-9. 